Article

\title{
Energy System Modelling of Carbon-Neutral Hydrogen as an Enabler of Sectoral Integration within a Decarbonization Pathway
}

\author{
Stavroula Evangelopoulou *, Alessia De Vita, Georgios Zazias and Pantelis Capros \\ E3MLab, Department of Electrical and Computer Engineering, National Technical University of Athens, 9 Iroon \\ Politechniou Street, Zografou Campus, 15773 Athens, Greece \\ * Correspondence: evangelopoulou@e3mlab.eu
}

Received: 13 June 2019; Accepted: 1 July 2019; Published: 2 July 2019

\begin{abstract}
This paper explores the alternative roles hydrogen can play in the future European Union (EU) energy system, within the transition towards a carbon-neutral EU economy by 2050, following the latest policy developments after the COP21 agreement in Paris in 2015. Hydrogen could serve as an end-use fuel, a feedstock to produce carbon-neutral hydrocarbons and a carrier of chemical storage of electricity. We apply a model-based energy system analysis to assess the advantages and drawbacks of these three roles of hydrogen in a decarbonized energy system. To this end, the paper quantifies projections of the energy system using an enhanced version of the PRIMES energy system model, up to 2050, to explore the best elements of each role under various assumptions about deployment and maturity of hydrogen-related technologies. Hydrogen is an enabler of sectoral integration of supply and demand of energy, and hence an important pillar in the carbon-neutral energy system. The results show that the energy system has benefits both in terms of $\mathrm{CO}_{2}$ emission reductions and total system costs if hydrogen technology reaches high technology readiness levels and economies of scale. Reaching maturity requires a significant investment, which depends on the positive anticipation of market development. The choice of policy options facilitating visibility by investors is the focus of the modelling in this paper.
\end{abstract}

Keywords: hydrogen; sectoral integration; decarbonization; energy system model

\section{Introduction}

Within the Paris Agreement, the European Union (EU) has committed to limit greenhouse gases (GHG) emissions to levels as low as needed to stay well below a $2{ }^{\circ} \mathrm{C}$ rise in the global temperature $[1,2]$ and preferably to $1.5^{\circ} \mathrm{C}$ [3]. Several roadmaps and studies have identified that energy efficiency improvement in all sectors, in particular of the buildings stock, and the large deployment of renewable energy sources in the power system, constitute the two basic pillars of a deep GHG emissions reduction pathway [4-7]. Also, carbon-free electricity can be an energy carrier that enables $\mathrm{CO}_{2}$ emission reductions in mobility and heat uses of energy, where it is cost-effective, thus, acting as a sectoral integration option. Energy efficiency, renewables and electrification can lead to strong GHG emission reductions ( $80 \%$ emission reductions in 2050 compared to 1990 levels of emissions in the EU), compatible with $2{ }^{\circ} \mathrm{C}$ pathways. However, a significant amount of GHG emissions persist in 2050, mainly due to fossil fuel combustion in the transport sector and the remaining uses of gas in buildings and industrial applications. To adopt more ambitious pathways that are in line with the enhanced ambition depicted in the Paris agreement $\left(1.5^{\circ} \mathrm{C}\right.$ pathway), even such remaining emission sources should be mitigated.

To this end, enhancing sectoral integration through the potential emergence of carbon-neutral energy carriers, like hydrogen, are candidate options. Sectoral integration may include hydrogen 
combustion in end-uses of energy, use of hydrogen as a feedstock to produce synthetic methane and liquid hydrocarbons, which would all also serve the chemical storage of electricity. Hydrogen development at a full systems' level has been proposed as a potential pathway to a decarbonized energy system [8-12]. Hydrogen qualifies as free of GHG-emissions (GHG-free) when both the feedstock and production (e.g., electricity for electrolysis, methane reforming) are free of emissions. Synthesis of hydrogen and carbon dioxide to produce methane [13] or liquid hydrocarbons [9] has to use GHG-free hydrogen and non-fossil $\mathrm{CO}_{2}$ feedstock, to qualify as GHG-free. The potential of hydrogen or hydrogen-based synthetic fuels has been analyzed in several studies with a focus either on national [14-17], regional [18] or global scale [19].

In this paper, we assess from a systems perspective, the three potential roles of hydrogen in the future EU energy system and their interplay with electricity. The authors enhanced the PRIMES model [20] to represent in detail the technologies and the process flows that relate electricity and hydrogen in the energy system, as well as the economic competition among technology options. The enhanced model includes all energy demand and supply sectors and covers alternative processes and technologies of hydrogen production, synthetic methane and liquid hydrocarbons, GHG-free capture of carbon dioxide and chemical storage of electricity. Dynamic investment and technology vintages, coupled with learning-by-doing, allow simulating dynamic transition pathways towards a restructured and carbon-neutral energy system. To explore uncertainties, we vary the technical-economic features of the new technologies, which then influence technology choice and investment, modify the pace of approaching industrial maturity and consequently, the long-term market potential of hydrogen.

In the context of contrasting scenarios with varying technological assumptions, the paper explores the uncertainties associated with each potential hydrogen role and outlines their benefits and drawbacks. Based on this assessment, the paper defines a balanced scenario, with a particular focus on market segments where industrial maturity of hydrogen technologies is most likely and can provide the greatest advantages. The scenarios are fully-fledged energy system projections for all EU Member States up to 2050 and have been prepared for this paper exclusively.

The current paper is structured as follows: Section 2 summarizes the key hydrogen uses and production routes; Section 3 presents and discusses the three distinct hydrogen roles in the energy system and analyses the quantified scenarios; Section 4 presents a short description of the enhancement of the PRIMES energy system model; Section 5 analyzes the simulation results; while Section 6 provides a discussion and the final section concludes.

\section{Overview of Technical-Economic Features of Hydrogen Use and Production Technologies}

Hydrogen has the potential to occupy a significant place in the transition towards a low-carbon energy system, as it can cover several roles within the energy system and have a zero-GHG footprint along the entire lifecycle. Today, hydrogen is used mainly in industrial applications as a feedstock (e.g., in fertilizer production), in the petrochemicals industry and refineries [21]. Several small and medium-scale hydrogen projects in Europe demonstrate novel uses of hydrogen in energy and industrial applications [22]. More specifically, hydrogen can be used of as a fuel in transport, for the cogeneration of heat and electricity, as a direct fuel and feedstock in industry, as a carrier of chemical storage of electricity, or as a feedstock in the synthesis of methane and liquid hydrocarbons.

Apart from hydrogen use in low and medium temperature applications in buildings and industry, injecting hydrogen in industrial high-temperature furnaces also has a potential. A notable example, for which demonstrations already exist at an industrial scale, is the direct reduction of iron ore via the use of hydrogen instead of coke [23]. Industrial symbiosis concepts can boost hydrogen penetration, as the by-products of hydrogen production via a steam-methane reforming (SMR) process, i.e. $\mathrm{CO}_{2}$, can serve, together with hydrogen, the synthesis of chemical substances further processed in the chemical industries [23].

The use of hydrogen in transport depends on fuel cells, which are currently expensive and have an uncertain learning-by-doing potential [24]. However, fuel cells are a suitable alternative 
for high-mileage and heavy-duty transport, such as buses, coaches, trucks, ships and trains [25-29]. Infrastructure development is also crucial for the refueling of fuel cell transport means. Economies of scale are important for the cost of hydrogen refueling stations. It is, therefore, reasonable to envisage investment in refueling hubs at least of a medium scale, where it may be economical to integrate the production of hydrogen and storage on-site [30-32].

Fuel cells for heating in the buildings sector [33] cover a small niche market of micro-cogeneration applications (micro-CHP) [34,35]. Hydrogen may have a larger potential in heating when supplied to the domestic sector through the gas distribution systems. Blending hydrogen into natural gas distribution pipelines is technically and economically possible, albeit up to $15 \%$ vol [36]. Higher blending rates imply significant investment to change the technical features of appliances. Large-scale distribution of hydrogen via dedicated pipelines and storage facilities requires high amounts of investment which may pay-off if hydrogen becomes a dominant option in heating.

Electricity generation using fuel cells is limited to heat and electricity cogeneration applications, with an overall energy efficiency between $65-75 \%$ [37]. Hydrogen can also be used to generate electricity from gas and steam turbines, which need technical adaptation for the use of hydrogen. Existing gas turbines can be converted to burn hydrogen at an affordable cost [38], by producing hydrogen from electrolyzers at times when appropriate resources are available (e.g., abundant renewables) as well as using hydrogen to generate electricity when the resources are not available; i.e., in a chemical electricity storage cycle. As this way of storage is versatile, covering all timeframes, from hourly to seasonal storage cycles, chemical storage based on hydrogen can maximize the use of variable renewables in the power sector. The overall energy efficiency rate of a cycle of chemical storage is between $42-50 \%$, but the energy input is not exhaustible if based on renewables.

The technologies that produce synthetic methane and liquid hydrocarbons use hydrogen and $\mathrm{CO}_{2}$ as inputs. Both inputs have to be GHG-free over their lifecycle to qualify the final product also as a GHG-free fuel when combusted in end-use applications. The $\mathrm{CO}_{2}$ feedstock may originate from the atmosphere (direct air capture-DAC), biomass (e.g., biomass gasification or biogas upgrading plants) or carbon capture technologies applied on fossil fuel power plants and boilers combusting fossil fuels or from industrial processes [39]. Several hydrocarbon synthesis technologies exist, e.g., methanation processes, methanol route processes and Fisher-Tropsch, which are known, albeit yet immature at an industrial scale [39-43]. Power-to-gas or power-to-liquid is a facility that integrates hydrogen production, $\mathrm{CO}_{2}$ injection, and possibly $\mathrm{CO}_{2}$ capturing, with the synthesis of hydrocarbons and can also serve as versatile chemical storage of electricity allowing maximum use of renewables [44]. The synthetic gas is greatly advantageous for not requiring modification of gas distribution and gas using appliances. However, it is more expensive and more electricity-intensive than hydrogen.

The main uncertainty concerns the costs of hydrogen production, $\mathrm{CO}_{2}$ capture from the air or biomass (to ensure full carbon neutrality for the entire chain) and the synthesis of hydrocarbons. The technologies are currently at a medium technology readiness level (TRL), i.e., 5-7 [45-47], have poor overall energy efficiency [48] and high investment costs [47-49]. However, optimism prevails in the literature regarding the learning potential that justifies considering hydrogen among the promising technologies in decarbonization pathways $[47,50,51]$.

The literature [51] categorizes hydrogen production systems in three groups depending on emissions:

- Grey hydrogen refers to production via the conventional SMR process using natural gas or naphtha, which emits $\mathrm{CO}_{2}$ at least as much as natural gas combustion.

- Blue hydrogen also refers to the SMR technique but applies carbon capture and storage (CCS), thus avoiding between $90-98 \%$ of $\mathrm{CO}_{2}$ emissions.

- Green hydrogen refers to production via the electrolysis process using carbon-free electricity (e.g., solar, wind, hydro, nuclear or CCS). 
Currently, on-site production of hydrogen via SMR using natural gas or naphtha is the dominant industrial practice due to low costs; however, grey hydrogen is not GHG-free [52]. Blue hydrogen production technology is mature, (TRL 9, [52]), but the large-scale application requires the availability of infrastructure for $\mathrm{CO}_{2}$ storage in underground geological structures, which currently do not exist in the EU and are considered undesirable in most EU Member States [53-55]. There are expectations that $\mathrm{CO}_{2}$ storage will gain certain permission in the long-term, although at a limited extent. The scarcity of $\mathrm{CO}_{2}$ storage would suggest using storage in priority for abating emissions in sectors that are difficult to decarbonize (i.e., industrial processes) or for ensuring negative emissions if required in the long-term.

Based on these considerations, the modelling has mainly retained green hydrogen for large-scale production of hydrogen in the long-term. However, blue hydrogen could be a valid option for on-site production of hydrogen in certain industrial complexes that are in the proximity of underground $\mathrm{CO}_{2}$ storage sites [56].

Alkaline electrolyzers are the best-practice technologies at present, due to lower costs compared to other technologies that are as yet immature. The investment cost is below $1000 \mathrm{EUR} / \mathrm{kW}$ [49], energy efficiency is 67-70\% [49] and they are close to full maturity (TRL 9, [47]). Other electrolysis technologies are the proton exchange membrane (PEM, with a TRL 8, [47]) and the solid oxide electrolyzer cell (SOEC, with a TRL 5, [43]). The PEM electrolyzers are expected to achieve higher efficiency rates than alkaline; however, both have similar prospects of investment cost reduction if developed at a large scale $[49,50]$. The SOEC electrolyzer is expected to reach the lowest electricity demand per unit of $\mathrm{H}_{2}$ produced among all electrolysis technologies. As a SOEC electrolyzer operates at high temperatures, it is suitable for coupling with highly exothermic processes as for the synthesis of hydrogen and $\mathrm{CO}_{2}$ for the production of synthetic liquid hydrocarbons [43]. Table 1 summarizes the assumptions regarding the levelized cost of hydrogen production, including the expected learning-by-doing effects in the long-term and the economies of scale [57].

Table 1. Levelized unit cost of hydrogen in EUR/MWh- $\mathrm{H}_{2}$.

\begin{tabular}{cccc}
\hline Hydrogen Production Technologies & $\mathbf{2 0 1 5}$ & $\mathbf{2 0 3 0}$ & $\mathbf{2 0 5 0}$ \\
\hline Alkaline Electrolysis, large scale & 92 & 89 & 90 \\
PEM Electrolysis, large scale & 99 & 85 & 90 \\
SOEC Electrolysis, large scale & 120 & 114 & 100 \\
Steam Methane Reforming, medium scale & 48 & 91 & 229 \\
Steam Methane Reforming with CCS, large scale & 107 & 133 & 267 \\
Alkaline Electrolysis, hub refueling station & 102 & 91 & 94 \\
PEM Electrolysis, hub refueling station & 120 & 97 & 95 \\
SOEC Electrolysis, hub refueling station & 143 & 128 & 105 \\
\hline
\end{tabular}

Notes: (a) Based on calculations by the authors, using data from the PRIMES model database; (b) the calculations assume electricity prices at 70 Euros/MWh, a discount rate of $8.5 \%$ and $\mathrm{aCO}_{2}$ emission allowance price escalating from $30 \mathrm{EUR} / \mathrm{tCO} 2$ in 2030 to $100 \mathrm{EUR} / \mathrm{tCO}_{2}$ in 2050 , (c) the figures in this table are only for illustration purposes, and the PRIMES model applies more complicated calculations and handles electricity prices, learning and choices as endogenous.

The electricity purchasing cost is the main element in the cost structure of hydrogen, followed by capital cost. The latter has a high reduction potential if electrolyzers develop at a large scale, but electricity remains the primordial cost factor. Producing electricity at times when renewables are abundant, and marginal costs in the power system are low is a way of optimizing electricity costs for hydrogen. Revenues of electrolyzers when producing reserve and flexibility services to the power system are also a cost-reducing element. For instance, the economies of scale related to the size of hydrogen production facility have a small contribution to total costs when comparing utility scale to the onsite production at a refueling hub. 


\section{Hydrogen Development Scenarios}

To explore the role of hydrogen in a decarbonized energy system, we first define and quantify three contrasting scenarios with distinct roles of hydrogen in an energy system. All three scenarios achieve the emissions reduction objectives of the EU until 2050, but differ as follows (see Table 2):

- Electrification scenario: Electricity dominates end-use applications, and hydrogen use is mainly used for chemical storage for electricity.

- Hydrogen economy scenario: Hydrogen becomes the dominant energy carrier in demand use sectors.

- Synthetic fuels scenario: Hydrogen serves as a feedstock for the production of synthetic, GHG-neutral methane and liquid hydrocarbons.

Table 2. Summary description of three stylized hydrogen pathways.

\begin{tabular}{|c|c|c|c|}
\hline & Hydrogen as Storage & Hydrogen as Energy Carrier & Hydrogen as Feedstock \\
\hline $\begin{array}{l}\text { Disruptive } \\
\text { Elements }\end{array}$ & $\begin{array}{c}\text { Electric aircraft, vessels, } \\
\text { long-haul trucks, } \\
\text { high-temperature heat } \\
\text { pumps in industrial sectors }\end{array}$ & $\begin{array}{l}\text { Direct use of hydrogen in } \\
\text { industrial uses. Replacement } \\
\text { of natural gas in gas } \\
\text { distribution. Major role in } \\
\text { heavy-duty transport means }\end{array}$ & $\begin{array}{l}\text { Development of a } \\
\text { value-chain for the } \\
\text { production of synthetic } \\
\text { fuels. }\end{array}$ \\
\hline $\begin{array}{c}\text { Major } \\
\text { uncertainties }\end{array}$ & $\begin{array}{l}\text { The technological and } \\
\text { economic success of certain } \\
\text { electricity technologies in } \\
\text { end-uses of energy }\end{array}$ & $\begin{array}{l}\text { High capital costs of } \\
\text { transmission, distribution and } \\
\text { storage of } \mathrm{H}_{2} . \text { Safety and } \\
\text { public acceptance concerns. } \\
\text { Significant increase in total } \\
\text { production of electricity. }\end{array}$ & $\begin{array}{l}\text { Costs of producing the } \\
\mathrm{CO}_{2} \text { feedstock to get } \\
\text { carbon neutrality. } \\
\text { Significant increase in } \\
\text { total production of } \\
\text { electricity. }\end{array}$ \\
\hline Benefits & $\begin{array}{l}\text { Efficient energy system due } \\
\text { to the electrification of } \\
\text { end-uses. Limited increase } \\
\text { in electricity demand } \\
\text { compared to other cases. }\end{array}$ & $\begin{array}{l}\text { Can theoretically cover the } \\
\text { energy almost the entire } \\
\text { energy system (including } \\
\text { storage needs) at } \\
\text { affordable costs. }\end{array}$ & $\begin{array}{l}\text { Consumers maintain } \\
\text { convenience and } \\
\text { distributors maintain the } \\
\text { infrastructure as of today. }\end{array}$ \\
\hline
\end{tabular}

\subsection{Electrification Scenario: Hydrogen for Electricity Storage in a Maximum Electrified Energy System}

Power generation is fully decarbonized and based mainly on renewables, with nuclear and CCS having a modest share. The variable renewables reach a high share, close to $85 \%$, by 2050 , whereas the contribution of nuclear and CCS is relatively small, in particular for the share of CCS due to $\mathrm{CO}_{2}$ storage limitations. Versatile storage facilities based on batteries in various scales and chemical storage based on hydrogen allow effective balancing of variable renewables. Therefore, the role of gas in the power system becomes less important in the long-term, compared to early stages of the transition, and so storage and flows over interconnections are the main sources of flexibility and reserves in the system.

Based on the assumption that novel electricity technologies reach economic and technical maturity in end-uses, electricity can dominate final energy demand in all sectors. Total demand for electricity increases when compared to a baseline projection, but because electric appliances and vehicles are particularly efficient, the increase in demand for electricity is moderate and does not challenge the power generation resources. Total demand for gas decreases very substantially in this scenario, in both the supply and the demand sectors of energy. Transportation relies on electricity to a very large extent, with advanced biofuels covering the fueling of transport modes such as aviation and shipping, which cannot electrify fully. The energy system is, therefore, carbon neutral by 2050, electricity is the dominant energy vector, and hydrogen is also an important means of storage of electricity, albeit without any significant contribution in final energy demand.

The majority of electric end-use technologies are mature today, (i.e., heat pumps, electric vehicles, railways, low-temperature industrial uses) and also able and very efficient, compared to technologies running on combustible fuels. However, considerable uncertainty surrounds the future development 
of novel electric technologies that are necessary to electrify the energy uses that, currently, mature technologies cannot cover. Most of the novel technologies of this kind (e.g., long-distance heavy-duty vehicles, coaches, aircraft, ships, high-temperature heat pumps, fully electric industrial processes and others) are currently at the stage of laboratory development, and only a few are in a demonstration phase [58-60].

From today's perspective, the electrification of certain transport modes is expected to be particularly challenging, as batteries do not provide the necessary energy density for performing long inter-urban trips, or long-distance airplane flights; the weight of the batteries needed to perform a transatlantic flight makes the total weight of the aircraft prohibitive. Short-distance flights using electric aircraft are in an early prototyping phase, and commercial applicability is expected only after 2030 [59]. Similar prospects are in consideration for electric vessels and ships. Decarbonizing long-distance road freight transportation via electric heavy good vehicles would require either an extremely dense recharging infrastructure network, or an extensive overhead wire network to be available along a significant part of the lengthy European motorways [58].

Electrifying residential and commercial/public buildings sector seems doable and cost-efficient, as the performance of heat pumps has been improving rapidly over the recent years [34]. Backup systems, which will eventually use gas, would, however, be needed, particularly in colder climates. Although low-enthalpy industrial applications can rely on electricity using current technologies, high-enthalpy heat and steam need novel technologies, e.g., high-temperature heat pumps that have not yet reached technological maturity [60]. Extensive electrification implies redesign of whole value-chains in some sectors (e.g., metals, chemical industry and others), while in others, e.g., glass production, it may need small-scale modifications [61].

The electrification of the entire final demand, including heat and mobility, involves a strong seasonal variation of electricity load which, combined with the high variability of the renewables, implies a huge increase in the demand for reserve and balancing power. The seasonal variability needs electricity storage with seasonal possibilities, as the provision of seasonally variating reserves by thermal power plants is particularly costly in capital terms. The storage systems with daily and hourly storage cycles (batteries, pumping, Compressed Air Energy Storage-CAES) cannot cover seasonal variation patterns. The storage portfolio has to include versatile storage systems with different storage cycle timeframes and flexibilities of activation. Batteries, hydro-pumping and chemical storage based on hydrogen are all necessary within the optimum storage portfolio. The high electrification strategy that does not develop chemical storage based on hydrogen, cannot achieve storage optimality and thus suffers from high costs and emissions due to the use of fossil fuel plants for reserve and balancing.

\subsection{Hydrogen Economy Scenario: Hydrogen as an End-Use Energy Commodity}

The concept of hydrogen as a universal carrier for all energy uses, broadly referred to as a "hydrogen economy", has been widely discussed since the 1970s [62]. The urge for achieving net-zero GHG emissions, following the inclusion of a $1.5^{\circ} \mathrm{C}$ context in the final text of the Paris Agreement, brought the hydrogen economy concept back into the agenda. Available technology can support hydrogen use in all sectors. The combustion of hydrogen can cover all industrial energy applications and replace all fossil-fuel applications, e.g., for high and low enthalpy heat, direct reduction of iron ore, chemistry, steam, cogeneration of heat and electricity, etc. Fuel cells can be the powertrain of all sorts of vehicles. Hydrogen technologies are also available for shipping and trains. As far as airborne transportation is concerned, it is yet not clear whether a hydrogen-fueled aircraft can reach technological maturity [24]. In the domestic sector, hydrogen can replace fossil fuels for heating and cooking purposes and distributed gas, albeit at the cost of changing in the design of appliances [63].

The wide use of hydrogen, also in low-pressure gas distribution and refueling stations, necessitates a dense hydrogen network and storage system. Modifying the existing gas infrastructure for hydrogen use is technically possible. However, uncertainty still surrounds the costs of infrastructure transformation and the implementation burden [30]. Acceptability issues reflecting security and 
leakage concerns may arise. Large-scale applications of hydrogen, for example in industrial complexes, large refueling hubs, etc., may benefit from electrolyzers installed locally and from a small-sized hydrogen transportation network and storage facilities located on-site at relatively low cost. The decarbonization of the buildings sectors would require hydrogen to flow in the distributed gas mix above $15-20 \% \mathrm{vol}$, which is the currently agreed blending limit for the existing infrastructure [36].

The wide use of hydrogen in all sectors does not cancel electrification in those segments of mobility and heat uses where it is cost-effective to electrify. Some examples are mobility in cities, heat-pumps in well-insulated houses and buildings, and certain electro-technologies in industry. A simple calculation indicates that complete coverage of all energy needs by hydrogen would require huge amounts of electricity to generate, and that would challenge resources, including renewables, and networks. It is thus imperative, to complement hydrogen development by electrification, where possible, and strong energy efficiency improvement in all sectors, and thereby limiting the total amounts of hydrogen to comply with sustainability.

Hydrogen replaces natural gas in heat uses and part of liquid fuels in transport. Despite electrification and efficiency in end-uses that moderate total amounts of hydrogen, the power sector will need to produce significantly higher amounts of electricity, compared to the electrification scenario, as hydrogen is mainly produced by electrolyzers to ensure full carbon neutrality. As renewables constitute the main source of electricity, the power system will require further expansion of storage systems, interconnections and grid reinforcement, significantly above the electrification scenario, to ensure balancing and reliability of supply.

\subsection{Synthetic Fuels Scenario: Hydrogen as a Feedstock for the Production of Synthetic Hydrocarbons}

Synthetic methane and liquid hydrocarbons constitute an option that can effectively address the drawbacks of the hydrogen scenario regarding distribution systems and end-use equipment and vehicles. The synthetic fuels (produced from a synthesis of hydrogen or syngas and carbon dioxide) are fully fungible to fossils and allow maintaining current infrastructure and equipment without any disruptive change.

The technologies for synthetic fuels are not novel [64] but are far from being industrially mature. Several demonstration plants are in operation in Europe. However, the estimated costs and energy efficiency rates are disappointing when compared to fossil fuels. The synthetic fuels are currently at least two or three times more expensive than the corresponding fossil fuels. Also, both carbon and hydrogen feedstocks have to be carbon neutral over their lifecycle to achieve carbon neutrality in the overall energy system [65].

The carbon feedstock has to be of biogenic origin [66] or captured from the atmosphere using DAC technologies [67-69], to render the fuels GHG-free. The anticipated learning potential as presented by private start-up companies and other sources could lead to average capturing costs below 200, or even 100 Euros/ton of $\mathrm{CO}_{2}$ captured [57,69], while costs are currently far higher (600-1000 Euros/ton of $\left.\mathrm{CO}_{2}\right)[67,68]$. Carbon feedstock from biogenic sources proves to be cheaper, in particular when $\mathrm{CO}_{2}$ is a by-product of another application (biomass used for energy in the paper and pulp industry, biogas upgrading to biomethane, $\mathrm{CO}_{2}$ capturing in a biomass firing power plant, etc.). The biogenic sources face limits in their overall potential. Using $\mathrm{CO}_{2}$ captured from fossil fuel power plants or industrial processes does not allow qualifying the synthetic fuels as GHG-free, as the $\mathrm{CO}_{2}$ captured is again released in the atmosphere during fuel combustion.

Another important consideration that limits the overall supply potential of synthetic fuels is the amount of electricity needed for production. Electricity needed for synthetic fuels is higher than that for hydrogen. The total volume of electricity can reach unsustainable levels if synthetic fuels replace all amounts of fossil fuels used at present. For this reason, a synthetic hydrocarbons strategy has to include strong energy efficiency efforts and electrification of end-uses, where this is cost-effective, to limit demand for synthetic fuels as much as possible. For the same reason, the strategy should also maintain the use of significant amounts of advanced biofuels in transport. 
Nonetheless, total power generation will inevitably increase considerably in a synthetic fuels strategy. The power system may reach potential limits of renewables, and bear high costs of grid development and procurement of balancing, storage and grid resources. Not all countries in the EU have sufficient potential for renewables to produce synthetic fuels domestically. They will rely on imports from other EU countries (or from outside the EU). Security of supply at a national level will depend on the integration of the EU market. The gas infrastructure is of particular interest to this respect. Transporting synthetic methane within the EU while still achieving security of supply standards will require investment in gas pipelines following a network topology much different than the current topology of the gas pipeline system. Today, the topology mainly serves transportation of gas from the East to the West. Within a synthetic methane future, the grid must be meshed and serve all directions, mainly from the periphery (North, South and West) to Central and Eastern Europe, due to the different potential of renewables in different EU regions.

\subsection{Balanced Scenario: Balanced Development of Hydrogen and Electrification}

The three hydrogen scenarios defined so far are stylized representations of different roles of hydrogen in the carbon-neutral system. The purpose was to explore the pros and cons of these distinct roles. All of them present serious uncertainties, mainly because they foresee an extreme development of certain technologies probably beyond their capabilities.

Therefore, a cost-effective approach that uses the options in a balanced way has to ensure picking up the most appropriate technology for each application and avoid using technologies that are unlikely to become mature in the future. The balanced technology application concept has guided the design of a balanced scenario, which combines the most cost-effective sectoral applications explored in the three previous scenarios.

The balanced scenario, maintains the basic decarbonization pillars, in the same logic as in the three previous scenarios as in [70]. Strong energy savings in buildings and industrial sectors driven by energy efficiency policies are important because of cost-efficiency and because they reduce the need to expand the power sector for producing alternative fuels. The dominance of renewables in the energy system is driven by carbon prices and mandatory renewable targets, in particular in the power sector as it is the main available and affordable option to decarbonize electricity. Electrification in the transport sector and stationary heat applications achieves efficiency and limits the total needs for alternative fuels, in particular in the market segments where electricity has a cost-effectiveness advantage. The development of advanced biofuels decarbonizes segments of transport markets which are difficult to electrify and therefore limits the needs for alternative fuels. Thus, efficiency, electrification and biofuels are valid options for most of the energy uses. Alternative fuels cover the remaining market segments, and still the production of hydrogen, methane and liquids from electricity and captured carbon dioxide, implies a significant increase in the size of the power sector and considerable development of the carbon dioxide capture technology.

The balanced scenario foresees:

- $15 \%$ vol share of hydrogen in the distribution gas network and mix of bio-methane and GHG-free synthetic methane;

- Direct use of hydrogen in heavy-duty transport means via fuel cells;

- Direct injection of hydrogen in high-temperature industrial processes (e.g., iron and steel, chemical industry, glass industry and other sectors);

- Use of hydrogen as a feedstock for ammonia and chemicals;

- Use of fuel cells in cogeneration of heat and power in large-scale heat uses;

- Use of hydrogen in facilities providing chemical storage of electricity.

GHG-free hydrogen is produced by electrolyzers fed by GHG-free electricity (i.e., green hydrogen). GHG-free methane complements hydrogen in gas distribution and is produced using non-fossil $\mathrm{CO}_{2}$. 
The balanced scenario foresees production of relatively smaller amounts of synthetic methane and fuels compared to the synthetic fuels scenario. Thus, the increase in the size of the power sector is significant but manageable, and the volume of carbon dioxide capture from the air and biogenic sources is also lower. In this way, carbon capture, biomass and renewable resources for power generation remain well below their potential, thus avoiding nonlinear increasing costs.

\section{Modelling Approach}

The PRIMES energy system model represents all demand and supply sectors in separate modules. The model formulates a typically nonlinear and intertemporal optimization model for each sector, as a typical decision problem formulated structurally following the microeconomic theory. The formulation by sector embeds engineering details of technologies and technical restrictions in the economic, behavioral problem. The algorithms solve a mathematical optimization program for some modules and a mixed nonlinear complementarity problem for others. Thus, the model derives energy consumption, energy supply and investment depending on prices derived from other modules. The pricing modules calculate supply costs by sector and determine prices by sector of product use based on marginal costs and an allocation of fixed and capital costs depending on assumptions about market conditions. A market balancing routine ensures demand and supply equilibrium in all markets simultaneously, and determines market clearing prices, after iterations involving all the modules. The model includes an endogenous mechanism for EU emission trading system (ETS) carbon prices and represents several policy instruments of different natures, e.g., taxes, subsidies, measures removing barriers, infrastructure investment, technology standards, emission or efficiency performing standards, policy targets and others. Usually, the model supports an impact assessment of policies by comparing a policy scenario to a non-policy one. The results provide projections of the energy system, investment, prices, costs and emissions until 2070 for each European country.

The model enhancements introduced by the authors concern both demand and supply modules. Briefly, the enhancements were as follows:

- The extension of the industrial energy demand module added technologies that use hydrogen directly in high-temperature applications, notably in iron and steel for direct reduction of iron ore, in furnaces and in the chemical industry as a fuel and as a feedstock to synthesize petrochemicals together with captured $\mathrm{CO}_{2}$.

- The extension of the gas distribution module added the possibility to blend hydrogen, biofuels and GHG-free synthetic methane depending on exogenously defined blending ratios. The gas mix has a GHG emission factor lower than natural gas and allows final demand users to comply with emission constraints, along with other measures such as energy efficiency improvement.

- A new module represented the production of hydrogen, the capture of $\mathrm{CO}_{2}$ from DAC and biomass (capture from fossil fuel combustion existed in the model) and production of GHG-free methane and liquid hydrocarbons, as well as the distribution of hydrogen either independently or injected in the gas distribution system. The module calculates feedstock inputs to the production of synthetic fuels, choice of technologies (among electrolyzers and production routes for synthetic fuels), learning-by-doing, prices of the outputs and distribution costs. In this way, the module determines the prices of the synthetic fuels by consumption sector.

- The extension of the power sector model added the representation of chemical storage of electricity and the modelling of synchronous operation of power generation, load, renewable resources, storage of the chemical storage inputs and the charging and discharging of the various storage systems. Investment in storage systems, regarding the volume and the choice of technology mix, is endogenous depending on costs of storage, the prices of the storage inputs and, the marginal costs of the power systems that further depend on the availability of renewable resources and the demand by end-users for hydrogen and synthetic fuels. In this manner, the production of hydrogen and synthetic fuels takes place at times when renewables are abundant and depending on fuel storage volumes renewables may maximize while seasonal and daily storage of electricity balances 
the renewables fully and affordably. The power sector model also solves the interconnected system of all European countries simultaneously, and thus captures the sharing of balancing resources and the access to remotely located renewables to cover all countries via an extended grid system. At present, the model includes a simplification assumption that every country produces hydrogen and synthetic fuels in their own territory to cover domestic uses.

- A module takes care to balance the capturing of carbon dioxide through several ways, competing against each other (DAC, biomass, combustion, industrial processes) and the use of carbon dioxide as a feedstock for synthetic fuels and its sequestration in materials (e.g., feedstock for chemical substances) and underground caverns. The module determines the mixes in production and uses depending on the potentials of each option in production and type of use or sequestration, the nonlinear cost-potential curves per option and the emission constraints (reflecting policy standards).

- Finally, the calculation of overall costs and various policy indicators has been extended to include investment and costs related to hydrogen and synthetic fuels.

\section{Results}

By design, all four scenarios achieve similar $\mathrm{CO}_{2}$ emission reductions by 2030, as they incorporate the same assumptions underpinning the successful implementation of the policies included in the "Clean Energy for All Europeans" package [71]. Also, all four scenarios achieve deep decarbonization objectives until 2050 (Table 3), which is in line with a carbon-neutrality strategy foreseeing 95\% reduction of carbon dioxide emissions from energy and industrial sectors by 2050, compared to 1990 emission levels in the EU. Compared to the $80 \%$ emissions reduction strategy for 2050, as in [71], the $95 \%$ emissions reduction strategy abates remaining emissions mainly in mobility and heat uses (primarily using natural gas). Deep emissions abatement is meant to concern the emissions remaining after achieving the $80 \%$ emissions reduction target.

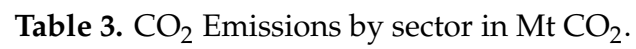

\begin{tabular}{|c|c|c|c|c|c|c|}
\hline European Union & & & $\begin{array}{l}\text { Electrification } \\
\text { Scenario }\end{array}$ & $\begin{array}{l}\text { Hydrogen } \\
\text { Economy } \\
\text { Scenario }\end{array}$ & $\begin{array}{c}\text { Synthetic } \\
\text { Fuels } \\
\text { Scenario }\end{array}$ & $\begin{array}{l}\text { Balanced } \\
\text { Scenario }\end{array}$ \\
\hline $\mathrm{Mt} \mathrm{CO} 2$ & 2015 & 2030 & \multicolumn{4}{|c|}{2050} \\
\hline Total $\mathrm{CO}_{2}$ emissions & 3770 & 2484 & 210 & 205 & 204 & 199 \\
\hline \% change from 1990 & $-9 \%$ & $-40 \%$ & $-95 \%$ & $-95 \%$ & $-95 \%$ & $-95 \%$ \\
\hline $\begin{array}{l}\text { Industry (combustion } \\
\text { and processes) }\end{array}$ & 745 & 561 & 50 & 43 & 44 & 42 \\
\hline Domestic Sector & 668 & 335 & 34 & 36 & 32 & 31 \\
\hline Transport Sector & 1030 & 869 & 94 & 92 & 89 & 90 \\
\hline Energy Supply & 1326 & 718 & 32 & 34 & 39 & 36 \\
\hline
\end{tabular}

Source: PRIMES model projections for future years and Eurostat for past years.

The scenario design assumptions imply that hydrogen and GHG-free methane enable the deep abatement of emissions in the scenarios assuming the availability of alternative fuels, whereas novel electric equipment enables the deep abatement in the electrification scenario. Table 3 shows that in all energy sectors, the carbon emissions remaining in 2050 are very low compared to historical levels.

The total amounts of biofuels and biomass are similar in all four scenarios due to limited potential. However, the use of biomass by sector differs across the scenarios. In scenarios with alternative fuels, it is relevant to use biofuels in transport mode segments where both electricity and hydrogen are difficult to apply, e.g., aviation, long-distance shipping and others. Biofuels also help to limit the total amounts of synthetic fuels and thus mitigate the electricity demand impacts in the power sector. Biomass combusted in cogeneration and heat plants is also similar in the four scenarios. Carbon capture 
applied on biomass-firing cogeneration plants is relevant in scenarios that involve the production of synthetic hydrocarbons, to limit the extent of applying carbon capture directly from the air.

Due to policy-related limitations in the existing in EU countries, all projections foresee a modest development of the underground storage of $\mathrm{CO}_{2}$. However, the capture of $\mathrm{CO}_{2}$ needs to develop in the scenarios that involve production if synthetic methane and hydrocarbons (Table 4). Capture from biogenic sources faces feedstock limitations, as the optimal use of biomass resources suggests producing advanced biofuels in priority to tackle emissions reduction in the most inflexible transport market segments. It is more economical to capture $\mathrm{CO}_{2}$ from power and heat plants using biomass rather than using biomass gasification. Carbon capture from power plants burning fossil fuels has a non-negligible potential in the scenarios, but its use as a feedstock to synthetic hydrocarbons is not consistent with carbon-neutrality. Sequestering underground or in materials (e.g., feedstock to a synthesis of petrochemicals) is, therefore, the only possibility for $\mathrm{CO}_{2}$ captured from fossil fuel combustion. Consequently, DAC of carbon dioxide will have to develop to a significant extent. Achieving the learning potential of DAC is important to mitigate cost impacts. The total volume to capture from the air remains within a reasonable range in the scenarios (Table 4), due to the limited volume of synthetic hydrocarbons foreseen in relevant scenarios.

Table 4. $\mathrm{CO}_{2}$ Capture, Use and Storage.

\begin{tabular}{|c|c|c|c|c|c|}
\hline European Union & & $\begin{array}{l}\text { Electrification } \\
\text { Scenario }\end{array}$ & $\begin{array}{c}\text { Hydrogen } \\
\text { Economy } \\
\text { Scenario }\end{array}$ & $\begin{array}{l}\text { Synthetic } \\
\text { Fuels } \\
\text { Scenario }\end{array}$ & $\begin{array}{l}\text { Balanced } \\
\text { Scenario }\end{array}$ \\
\hline $\mathrm{Mt} \mathrm{CO} 2$ & 2030 & \multicolumn{4}{|c|}{2050} \\
\hline $\mathrm{CO}_{2}$ capture & 5 & 84 & 90 & 680 & 401 \\
\hline from Air & 0 & 0 & 0 & 367 & 226 \\
\hline from Biomass & 0 & 0 & 0 & 157 & 97 \\
\hline from fossil fuel combustion & 5 & 84 & 90 & 155 & 79 \\
\hline $\mathrm{CO}_{2}$ use & 5 & 84 & 90 & 680 & 401 \\
\hline as feedstock & 0 & 0 & 0 & 581 & 337 \\
\hline stored underground & 5 & 84 & 90 & 99 & 64 \\
\hline$\%$ of emissions captured & $0.2 \%$ & $29 \%$ & $31 \%$ & $77 \%$ & $67 \%$ \\
\hline $\begin{array}{c}\% \text { of emissions stored } \\
\text { underground }\end{array}$ & $0.2 \%$ & $29 \%$ & $31 \%$ & $11 \%$ & $11 \%$ \\
\hline
\end{tabular}

Source: PRIMES model projections.

As mentioned above, reducing energy consumption is cost-effective and at the same time prevents the excessive increase in the size of the power sector, as electricity dominates energy supply, either as an energy carrier used directly or as a feedstock for hydrogen and synthetic hydrocarbons. Therefore, all four scenarios include strong energy efficiency-promoting measures, although they differ in terms of fuel mix (Table 5). However, the GHG-free fuels, when available in a scenario, constitute an alternative option for emissions reduction in final demand sectors, thus discouraging too high investment in deep energy renovation of buildings. Nonetheless, the trade-off between efficiency and GHG-free fuels in final consumption is small in magnitude, as both options are needed to decarbonize fully. Regarding total final energy consumption, the electrification scenario is $12 \%$ more efficient (calculated in terms of final energy consumption) than the synthetic fuels scenario, which is $5 \%$ less efficient than the balanced scenario and $2.5 \%$ less efficient than the hydrogen scenario.

Solid fuels vanish in final energy consumption under all scenario conditions. The decrease in the final consumption of liquid fuels is also impressive in all scenarios. The existence of GHG-free liquid fuel supply has a small effect on market shares of liquid fuels; in the relevant scenario, the liquids get a share of $11 \%$ in final energy consumption, which is considerably lower from the share of $39 \%$ in 2015 . The share of liquids is much smaller in the rest of the scenarios. Conversely, the share of gas (methane) in final energy consumption heavily depends on the availability of GHG-free gas supplied by the gas distribution system. The share of gas in total final consumption remains slightly above historical 
levels in the synthetic fuels scenario and also remains at a comparable level in the balanced scenario. Nevertheless, in the other two scenarios, electricity or hydrogen almost completely displace methane.

Table 5. Final Energy Consumption in Mtoe.

\begin{tabular}{|c|c|c|c|c|c|c|}
\hline European Union & & & $\begin{array}{l}\text { Electrification } \\
\text { Scenario }\end{array}$ & $\begin{array}{l}\text { Hydrogen } \\
\text { Economy } \\
\text { Scenario }\end{array}$ & $\begin{array}{c}\text { Synthetic } \\
\text { Fuels } \\
\text { Scenario }\end{array}$ & $\begin{array}{l}\text { Balanced } \\
\text { Scenario }\end{array}$ \\
\hline Mtoe & 2015 & 2030 & \multicolumn{4}{|c|}{2050} \\
\hline Total final consumption & 1136 & 954 & 727 & 808 & 830 & 788 \\
\hline \% change from 2015 & & $-16 \%$ & $-36 \%$ & $-29 \%$ & $-27 \%$ & $-31 \%$ \\
\hline Solids & 48 & 28 & 1 & 1 & 1 & 1 \\
\hline Liquids & 440 & 312 & 37 & 41 & 88 & 55 \\
\hline Gas & 266 & 192 & 24 & 14 & 217 & 109 \\
\hline $\begin{array}{c}\text { Renewables and } \\
\text { biomass/waste }\end{array}$ & 93 & 102 & 124 & 124 & 129 & 120 \\
\hline Hydrogen & 0 & 0 & 10 & 249 & 15 & 91 \\
\hline Steam & 49 & 42 & 42 & 38 & 38 & 39 \\
\hline Electricity & 241 & 278 & 489 & 341 & 342 & 373 \\
\hline Shares in \% & 2015 & 2030 & \multicolumn{4}{|c|}{2050} \\
\hline Solids & $4 \%$ & $3 \%$ & $0 \%$ & $0 \%$ & $0 \%$ & $0 \%$ \\
\hline Liquids & $39 \%$ & $33 \%$ & $5 \%$ & $5 \%$ & $11 \%$ & $7 \%$ \\
\hline Gas & $23 \%$ & $20 \%$ & $3 \%$ & $2 \%$ & $26 \%$ & $14 \%$ \\
\hline $\begin{array}{l}\text { Renewables and } \\
\text { biomass/waste }\end{array}$ & $8 \%$ & $11 \%$ & $17 \%$ & $15 \%$ & $16 \%$ & $15 \%$ \\
\hline Hydrogen & $0 \%$ & $0 \%$ & $1 \%$ & $31 \%$ & $2 \%$ & $12 \%$ \\
\hline Steam & $4 \%$ & $4 \%$ & $6 \%$ & $5 \%$ & $5 \%$ & $5 \%$ \\
\hline Electricity & $21 \%$ & $29 \%$ & $67 \%$ & $42 \%$ & $41 \%$ & $47 \%$ \\
\hline
\end{tabular}

Source: PRIMES model projections for future years and Eurostat for past years.

The remarkable increase of hydrogen as an energy carrier in the hydrogen economy scenario (where it gets a share of $31 \%$, Table 5), arises from the use of hydrogen mainly in the mobility sector (Table 6). In the same scenario, the market penetration of hydrogen in all other sectors is also significant. Hydrogen used as a feedstock is relevant only in synthetic fuels and balanced scenarios. In these two scenarios, the total amounts of hydrogen in 2050 are similar to those of the hydrogen scenario. However, the share of hydrogen used as a feedstock is much higher than in the hydrogen scenario, as expected. Unless electricity dominates as a carrier for end-uses, the system will require to produce between 305 and 340 Mtoe of hydrogen in 2050, which corresponds to the installation of 500 to 750 GW of electrolyzers in Europe; the market volume is huge for the electrolyzing industry, compared to current practices.

Table 6. Hydrogen utilization outlook.

\begin{tabular}{cccccc}
\hline European Union & & $\begin{array}{c}\text { Electrification } \\
\text { Scenario }\end{array}$ & $\begin{array}{c}\text { Hydrogen } \\
\text { Economy } \\
\text { Scenario }\end{array}$ & $\begin{array}{c}\text { Synthetic } \\
\text { Fuels } \\
\text { Scenario }\end{array}$ & $\begin{array}{c}\text { Balanced } \\
\text { Scenario }\end{array}$ \\
\hline Mtoe & $\mathbf{2 0 3 0}$ & \multicolumn{2}{c}{$\mathbf{2 0 5 0}$} \\
\hline Hydrogen-carrier & 0.4 & 16 & 305 & 31 & 102 \\
Energy supply & & 6 & 56 & 17 & 11 \\
Industry & & 0 & 65 & 5 & 28 \\
Domestic sector & 0.4 & 10 & 123 & 9 & 40 \\
Transport sector & & 0 & 0 & 314 & 177 \\
Hydrogen-feedstock & $0 \%$ & $0 \%$ & $91 \%$ & $63 \%$ \\
\hline \% share of hydrogen used as a feedstock & & & & & \\
\hline
\end{tabular}


The comparison between Tables 6 and 7 clearly shows that electricity and hydrogen are strong rivals in the market segments where both can be used directly. Electricity is at least twice more efficient than hydrogen in direct end-uses. Producing hydrogen from electricity implies $70-85 \%$ of losses of electricity. So, producing hydrogen in the hydrogen scenario to replace part of electricity in the end-uses, implies a far higher volume of electricity to generate, compared to the electrification scenario. The impact on electricity volumes further magnifies when also producing synthetic fuels, as in the synthetic fuels and the balanced scenario. As shown in Table 7, total electricity consumption has to increase in the scenarios with hydrogen and synthetic fuels between 1.4 to 1.5 times, compared to the electrification scenario.

Table 7. Electricity utilization outlook.

\begin{tabular}{cccccc}
\hline European Union & Electrification & $\begin{array}{c}\text { Hydrogen } \\
\text { Economy } \\
\text { Scenario }\end{array}$ & $\begin{array}{c}\text { Synthetic } \\
\text { Fuels } \\
\text { Scenario }\end{array}$ & $\begin{array}{c}\text { Balanced } \\
\text { Scenario }\end{array}$ \\
\hline Mtoe & $\mathbf{2 0 3 0}$ & & $\mathbf{2 0 5 0}$ & & \\
\hline Electricity-carrier & 278 & 489 & 341 & 342 & 373 \\
$\begin{array}{c}\text { Electricity-feedstock } \\
\text { Total }\end{array}$ & 0.5 & 20 & 381 & 431 & 350 \\
$\begin{array}{c}\text { \% share of electricity } \\
\text { used as a feedstock }\end{array} \%$ increase in total & 278 & 509 & 722 & 773 & 723 \\
electricity from 2030 & & $4 \%$ & $53 \%$ & $56 \%$ & $48 \%$ \\
\hline
\end{tabular}

Source: PRIMES model projections.

As nuclear and CCS have limited potentials in the EU's future power system, due to various policy and economic reasons, renewables need to expand considerably to cover the growing demand for electricity. The dispatchable renewables, such as hydro and biomass, have a limited potential and, consequently, the incremental development of renewables relies on variable renewables, such as solar and wind. The ensuing variability of the system will require huge flexibility resources, including versatile and seasonal storage. As shown in Table 8, irrespective of the total volume of electricity demand, the shares of renewables is roughly $85 \%$ by 2050 in all scenarios, as the other carbon-free generation options have limitations. Renewables need to be 1.6 times higher in the synthetic fuels scenario, and 1.5 times higher in the balanced scenario, compared to the electrification scenario. A synergy would, however, prove beneficial for the integration of renewables at such a large scale. Hydrogen and synthetic gas suitable for providing chemical storage services to the power sector, allow for maximizing the exploitation of renewables by producing the fuels when renewables are abundant, and eventually using the fuels when renewables are scarce. If the electricity interconnection system is sufficiently large enough and well-functioning, the increase in power generation and the ensuing increase in renewables are in great synergy with the development of chemical storage to ensure robustness, generation adequacy and affordable electricity prices (see the last line of Table 10). Selling hydrogen and synthetic fuels to end-users provides an additional benefit for the power system. More specifically, through the use of storage facilities located close to end-users, it is possible to further increase the renewables by producing hydrogen and synthetic fuels when renewables are abundant. This has been termed as "indirect chemical storage", and has a strong seasonal pattern bringing significant cost savings to the power sector. The electrification scenario does not include the production of synthetic fuels and hydrogen for end-users, and thus has limited resources of direct and indirect chemical storage. Maintaining reserve capacities other than chemical storage (complemented by batteries and hydro pumping) proves to be more expensive, as the reserve has to rely on gas power plants that are seldom used and are expensive when operating due to the cost of emissions. Therefore, despite developing much lower amounts of renewables, the average price of electricity is slightly higher in the electrification scenario compared to the scenario that develops hydrogen and synthetic fuels. 
Table 8. Power Generation Outlook.

\begin{tabular}{|c|c|c|c|c|c|c|}
\hline European Union & & & $\begin{array}{l}\text { Electrification } \\
\text { Scenario }\end{array}$ & $\begin{array}{l}\text { Hydrogen } \\
\text { Economy } \\
\text { Scenario }\end{array}$ & $\begin{array}{c}\text { Synthetic } \\
\text { Fuels } \\
\text { Scenario }\end{array}$ & $\begin{array}{l}\text { Balanced } \\
\text { Scenario }\end{array}$ \\
\hline TWh & 2015 & 2030 & \multicolumn{4}{|c|}{2050} \\
\hline Total Power Generation & 3091 & 3548 & 6499 & 9221 & 10337 & 9437 \\
\hline From Solids & 763 & 350 & 0 & 0 & 0 & 0 \\
\hline From Oil & 33 & 20 & 2 & 2 & 2 & 2 \\
\hline From Gas & 553 & 462 & 97 & 504 & 546 & 520 \\
\hline From Nuclear & 826 & 645 & 860 & 914 & 969 & 907 \\
\hline From RES & 916 & 2071 & 5540 & 7802 & 8820 & 8008 \\
\hline Shares in \% & 2015 & 2030 & \multicolumn{4}{|c|}{2050} \\
\hline From Solids & $24.7 \%$ & $9.9 \%$ & $0.0 \%$ & $0.0 \%$ & $0.0 \%$ & $0.0 \%$ \\
\hline From Oil & $1.1 \%$ & $0.6 \%$ & $0.0 \%$ & $0.0 \%$ & $0.0 \%$ & $0.0 \%$ \\
\hline From Gas & $17.9 \%$ & $13.0 \%$ & $1.5 \%$ & $5.5 \%$ & $5.3 \%$ & $5.5 \%$ \\
\hline From Nuclear & $26.7 \%$ & $18.2 \%$ & $13.2 \%$ & $9.9 \%$ & $9.4 \%$ & $9.6 \%$ \\
\hline From RES & $29.6 \%$ & $58.4 \%$ & $85.2 \%$ & $84.6 \%$ & $85.3 \%$ & $84.9 \%$ \\
\hline
\end{tabular}

Source: PRIMES model projections for future years and Eurostat for past years.

As shown in Table 8, the projections foresee the development of nuclear in 2050 slightly above the levels in 2015, as it is generally difficult for the EU to develop further greenfield nuclear. The share of nuclear drops to roughly $10 \%$ in 2050, significantly down from the share in 2015 . Power generation from coal or oil is incompatible with the emissions reduction objectives and strongly discouraged by the rising carbon allowances prices of the EU ETS auctioning system (which includes the market stability reserve regulations); carbon prices reach levels close to $300 € / \mathrm{tCO}_{2}$ in 2050 , significantly up from $35-40 € / \mathrm{tCO}_{2}$ in 2030 . The scarcity of CCS, due to limited underground storage possibilities in various countries (mainly due to policy), prohibits the development of fossil fuel burning generation. Electricity produced using natural gas is also non-economical in this context, and the small remaining amounts of natural gas burn in CCS power plants. Using GHG-free gas in power plants at a large scale is unsustainable because of the magnifying impacts on demand for electricity. Therefore, gas-based generation remains among the flexibility and reserve providers but essentially only via the chemical storage cycles. As shown in Table 8, the availability of synthetic gas in some scenarios allows for an increase in generation from gaseous fuels, compared to the electrification scenario.

Despite the substantial modification of the chemical origin of the molecules, total consumption of gaseous fuels, including hydrogen, remain in all scenarios at a level that is comparable to gas consumption in 2015 (Table 9). Nevertheless, the electrification scenario constitutes an exception, where the gaseous fuels drop to roughly one-third of the consumption levels in the other scenarios. However, the use of fossil gas is higher in this scenario compared to the others, as electricity cannot fully displace gas in all end-uses and in the power sector. Hydrogen mixed in gas distribution up to $15 \%$ vol (the maximum threshold for not replacing equipment) and substantially developed biogas are not enough to fully decarbonize the amounts of gaseous fuels needed in the various uses. The absence of large-scale hydrogen and synthetic gas in this scenario obliges the use of electricity in cases where it is probably not cost-effective and does not allow fully eliminating fossil gas.

In other scenarios, the supply of GHG-free gaseous fuels allows avoiding extreme electrification of demand for energy. In the two scenarios that produce synthetic hydrocarbons and thus need carbon capture from the air or biogenic sources, the scenarios foresee higher development of biogas, compared to other scenarios, because it is possible to capture carbon dioxide in the upgrade of biogas to biomethane in a non-expensive way.

Table 9 illustrates the tremendous benefits for the security of energy supply stemming from the replacement of fossil oil and gas in the energy system. Europe will need to import a small share of gaseous fuels by 2050 in the scenarios involving hydrogen and synthetic methane. The amounts 
of imported gas are also small in the electrification scenario, but in this case, due to the high use of electricity. The scenarios illustrate energy provision conditions that differ dramatically from the present situation. Energy independence is fully achieved, and the supply system relies entirely on domestic sources. The complex gas import, transport and storage infrastructure of Europe will have to be reorganized and oriented towards sharing the domestic resources effectively between the member-states.

Table 9. Gas utilization outlook.

\begin{tabular}{|c|c|c|c|c|c|c|}
\hline European Union & & & $\begin{array}{l}\text { Electrification } \\
\text { Scenario }\end{array}$ & $\begin{array}{l}\text { Hydrogen } \\
\text { Economy } \\
\text { Scenario }\end{array}$ & $\begin{array}{l}\text { Synthetic } \\
\text { Fuels } \\
\text { Scenario }\end{array}$ & $\begin{array}{l}\text { Balanced } \\
\text { Scenario }\end{array}$ \\
\hline Mtoe & 2015 & 2030 & \multicolumn{4}{|c|}{2050} \\
\hline Gaseous Fuels & 415 & 340 & 144 & 421 & 352 & 345 \\
\hline Natural Gas & 387 & 297 & 70 & 57 & 64 & 58 \\
\hline Synth. Methane & 0 & 0 & 0 & 0 & 176 & 115 \\
\hline Hydrogen & 0 & 0 & 16 & 305 & 31 & 102 \\
\hline Biogas & 8 & 29 & 57 & 57 & 79 & 68 \\
\hline Coal gases & 20 & 14 & 1 & 2 & 2 & 2 \\
\hline$\%$ fossils & $98 \%$ & $91 \%$ & $49 \%$ & $14 \%$ & $19 \%$ & $17 \%$ \\
\hline \multicolumn{7}{|l|}{ Gaseous Fuels } \\
\hline Natural Gas-Extraction & 134 & 76 & 14 & 11 & 12 & 12 \\
\hline Natural Gas-Net Imports & 253 & 221 & 56 & 46 & 53 & 46 \\
\hline Biogas & 8 & 29 & 57 & 57 & 79 & 68 \\
\hline Coal gases & 20 & 14 & 1 & 2 & 2 & 2 \\
\hline $\begin{array}{l}\text { Hydrogen and synth. } \\
\text { methane }\end{array}$ & 0 & 0.4 & 16 & 305 & 206 & 217 \\
\hline$\%$ imported & $61 \%$ & $65 \%$ & $39 \%$ & $11 \%$ & $15 \%$ & $13 \%$ \\
\hline
\end{tabular}

Source: PRIMES model projections for future years and Eurostat for past years.

Table 10 shows the impacts on costs of energy and investment expenditures, according to the model-based projections. All the indicators shown in the table are calculated using the model and are not estimations or expert-judgments. The indicator "total energy system costs" corresponds to annual costs that the end-users of energy incur to get the energy services and products, including the annuity capital costs of insulation of buildings, energy efficiency in industry, and the purchasing of all sorts of energy using equipment and vehicles in all sectors. The cost indicator represents the amount that the rest of the economy will have to pay to produce all energy services. In this sense, the indicator is a proxy of macroeconomic costs incurred by the scenario and can thus be used to compare scenarios for an economic assessment. The energy prices applying to the purchasing of energy products by end-users allow, as calculated by the model, to recover all sorts of costs of the energy production, transport and distribution system. According to the "total energy system costs" indicator, the deep decarbonization scenarios are more expensive in the period 2031-2050 than in 2021-2030. The increase in costs is $20 \%$ and is roughly the same for all four scenarios, which is a remarkable result in the sense that all four decarbonization scenarios imply similar total energy costs, although the fuel and technology mix changes significantly across the scenarios.

All four scenarios are capital intensive, as decarbonization depends on investment in all sectors, which reduces energy consumption and replaces fossils by renewables. Investment expenditures increase between 50 and 60\% in the period 2031-2050 (per year) compared to the period 2021-2030; the latter period is also more capital-intensive than in the past as the projections include policy targets for 2030. The balanced scenario is the most investment-intensive one, since, by design, it develops all options; opting for the most cost-effective options for each market segment, to ensure maximum feasibility, pays in terms of total investment. As expected, the operating expenditures, per year, born by end-users tend to decrease in all scenarios during the period 2031-2050 compared to the period 
2021-2030, thanks to energy efficiency, which offsets the effect of the increase in fuel prices driven by the high cost of producing hydrogen and synthetic hydrocarbons.

Table 10. Average annual total system costs, purchasing energy, investment expenditures and average electricity prices.

\begin{tabular}{|c|c|c|c|c|c|}
\hline European Union & & $\begin{array}{l}\text { Electrification } \\
\text { Scenario }\end{array}$ & $\begin{array}{l}\text { Hydrogen } \\
\text { Economy } \\
\text { Scenario }\end{array}$ & $\begin{array}{l}\text { Synthetic } \\
\text { Fuels } \\
\text { Scenario }\end{array}$ & $\begin{array}{l}\text { Balanced } \\
\text { Scenario }\end{array}$ \\
\hline & 2021-2030 & \multicolumn{4}{|c|}{ 2031-2050 } \\
\hline $\begin{array}{l}\text { Annual total energy system } \\
\text { costs, on average, Bn } €\end{array}$ & 1989 & 2372 & 2392 & 2394 & 2379 \\
\hline $\begin{array}{l}\text { Annual cost of purchasing } \\
\text { energy by end-users, on } \\
\text { average, Bn } €\end{array}$ & 1402 & 1357 & 1393 & 1472 & 1382 \\
\hline $\begin{array}{l}\text { Unit total cost of emission } \\
\text { reduction, on average, } \\
\text { in } € / \mathrm{tCO}_{2}\end{array}$ & 142 & 197 & 218 & 221 & 204 \\
\hline $\begin{array}{l}\text { Annual investment } \\
\text { expenditures, on average, Bn } €\end{array}$ & 453 & 692 & 686 & 709 & 729 \\
\hline Demand sectors & 338 & 461 & 459 & 431 & 480 \\
\hline Stationary energy uses & 281 & 301 & 286 & 287 & 324 \\
\hline Mobile energy uses & 57 & 159 & 174 & 143 & 156 \\
\hline Supply sectors & 115 & 231 & 228 & 278 & 249 \\
\hline Power grids & 59 & 130 & 111 & 115 & 119 \\
\hline $\begin{array}{c}\text { Power and Heat production } \\
\text { plants }\end{array}$ & 55 & 100 & 108 & 125 & 110 \\
\hline $\begin{array}{c}\text { Production of synthetic fuels } \\
\text { and } \mathrm{H}_{2}\end{array}$ & 0.1 & 1 & 9 & 39 & 20 \\
\hline $\begin{array}{l}\text { Average Electricity Prices, } \\
\text { in } € / M W h\end{array}$ & 155 & 160 & 158 & 156 & 157 \\
\hline
\end{tabular}

Source: PRIMES model projections.

Two-thirds of total investment expenditures take place in the energy demand sectors, of which two-thirds are for final stationary energy uses. The accounting of investment costs for mobility isolates the incremental investment needed to modify the fleet for achieving energy efficiency and emissions reduction and does not include the entire amount of investment for the transport fleet. Similarly, the accounting only includes investment for refueling and recharging for alternative fuels and not the entire amounts for refueling stations.

In the supply sectors, the large majority of investment expenditures take place in the power sector, as this sector becomes the direct or indirect supplier of all energies. Grids and power plants require high investment efforts and the amounts are roughly similar. Investment in power grids and power plants needs to double, on an annual basis, in contrast to the past. As mentioned above, despite the significant increase in investment and the overall size of the power sector, average electricity prices see only a small increase in 2031-2050, namely only $2.5 \%$ on average, compared to the prices in 2021-2030. It is worth noticing that the electrification scenario leads to slightly higher average electricity prices, compared to other scenarios, despite the significantly lower volume of total electricity generation and the total deployment of renewables. The reason is the lack of appropriate storage systems, notably chemical storage with seasonal possibilities. The lowest average electricity prices occur in the synthetic fuels scenario, which leads to the highest total volume of power generation and renewables but at the same time benefits from chemical storage directly, as well as from indirect storage effects of storing hydrogen and synthetic fuels in the facilities of the fuel distribution systems. 


\section{Discussion}

The research presented in this paper has aimed to model and analyze various possible contributions of hydrogen and GHG-free methane and liquid hydrocarbons in the context of the entire energy system of the EU along the transition pathway towards carbon neutrality by 2050. The research included data collection for the new technologies, and in particular regarding the learning potentials, enhancement of the large-scale model PRIMES and application of the model in the quantification of stylized pathways (scenarios). The scenarios share the same carbon-neutrality objective for 2050 but use different assumptions regarding which GHG-free energy carrier will dominate in the future. Candidates are electricity, hydrogen and GHG-free methane and liquid hydrocarbons. The technologies supporting each candidate carrier are different along the whole value chain, i.e., production, distribution and end-use equipment. However, all three carriers require electricity generation from renewables (with smaller contributions of nuclear and CCS) as a source.

Several of the technologies supporting each candidate carrier are not mature today and are also expensive. The industrial dynamics, as represented in the modelling of alternative scenarios, allocate increasing funding to the carrier and technologies that become dominant, allowing them to experience cost reductions from high learning, while the other, non-dominant, carriers are not achieving similar cost reductions. As total investment funding is limited, it is unlikely to see all carriers and technologies achieving high learning within the same pathway.

The three candidate carriers are supported by technologies with unequal technical and industrial readiness levels. Also, technology limitations exist that do not allow using a single carrier and technology-type in all applications of energy, unless some technologies experience breakthrough developments in the future. Given these limitations, a balanced approach may be attractive, consisting of using each carrier and technology where it is cost-effective without seeking a full dominance. However, pursuing the development of all carriers and technologies in parallel may imply higher costs than when a single carrier dominates.

The scenarios quantified after enhancing the PRIMES energy system model explore the strategic options regarding the choice of a single dominant carrier or opting for a balancing approach. The aim was to study these issues in the context of the entire energy system and not in a bottom-up approach as followed by the majority of the literature $[10,22,23,25,39-43]$. Only a few publications exist that study the future of hydrogen and GHG-free hydrocarbons in the context of the entire energy system. However, all the system modelling papers so far $([9,12-14])$ are applications of the TIMES-MARKAL model, which solves a single linear optimization problem for the entire energy system. Analyzing the same topic in the context of the energy market considering behaviors of agents and nonlinear technology dynamics and resource constraints is a very different approach, which is the aim of the PRIMES model approach. This constitutes the novelty of this paper with regard to the literature.

The modelling results for the four scenarios, also supported by numerous sensitivity analysis runs, confirms statements that have been mentioned in the literature but have not been fully quantified so far. The main findings are:

- For the electricity carrier, full dominance is difficult as electrification of certain energy applications is probably impossible. Also, the power system will incur high costs to balance load and renewables variability without seasonal storage facilities.

- Hydrogen becoming the dominant single carrier implies transforming and adapting the entire distribution infrastructure and the entire fleet of energy equipment, which is costly and uncertain.

- Replacing fossils by GHG-free methane and liquid hydrocarbons has the great advantage of maintaining current infrastructure and equipment. The serious uncertainty concerns the potential of cost reduction in the production of synthetic methane and liquids using hydrogen and non-fossil $\mathrm{CO}_{2}$ capture.

- To produce hydrogen and GHG-free hydrocarbons total electricity generation has to increase considerably, challenged by renewable energy potential and grid operation. However, the chemical 
storage of electricity enabled by hydrogen and synthetic methane is a cost-effective solution for power system balancing and electricity affordability.

- If the industry succeeds full achievement of the learning potential for technologies that are not fully mature today, the additional costs needed to reach carbon neutrality by 2050 are reasonably moderated. Financing the significantly increasing investment requirements is the main issue.

- The balanced approach is attractive because it does not rely on uncertain technological applications. Within this approach, electrification of end-uses applies on a large-scale but only where it is a cost-effective solution. Hydrogen develops for specific applications, but not as a universal carrier, thus avoiding investment in large-scale distribution and storage of hydrogen. Cost-effective applications of hydrogen exist for specific industrial processes and transport market segments. GHG-free hydrocarbons, mainly GHG-free methane, also develop but only to cover applications where maintaining the use of gaseous fuels is necessary. The amounts of electricity needed to produce hydrogen and GHG-free hydrocarbons represent a significant increase in the size of the power system, but the chemical storage enabled by these fuels allows maximizing development of renewables and balancing the power system variability cost-effectively.

The uncertainties that may undermine the validity of the findings mentioned above concern mainly the future costs of technologies that produce hydrogen and GHG-free hydrocarbons, including the technologies of capturing non-fossil carbon dioxide. The model applications in this paper assumed that the learning potential is achievable. The figures for the learning potential are in line with those mentioned in the recent literature and the estimations by the industry. However, all these sources provide a range of possibilities and not a single value for the long-term. If the pessimistic figures of this range prevail, the cost impacts of the carbon neutrality strategy will increase very significantly, especially for the scenarios involving hydrogen and GHG-free hydrocarbons. In this case, the electricity carrier strategy will constitute the best option, but the limitations of full electrification will remain.

The model applications have also assumed a well-functioning internal electricity market in the EU, a full market coupling and coordinated system management, as well as a substantial extension and reinforcement of the power transmission system and interconnections. These conditions are important to ensure the reliability of supply by an EU-wide power system that will be considerably enlarged in the future and fully dominated by variable renewables. The modelling results show that access to remotely located renewables and the combination of renewables with diversified time profiles are necessary for cost and balancing reasons. EU countries with low renewables resources will need to import electricity or electricity-based fuels from other EU countries that have renewables in excess. However, the full completion of the EU internal market and the extension of the infrastructure are uncertain, given the experience so far. Failures in this matter would entail high costs, threats on the security of supply and limits to full decarbonization.

\section{Conclusions}

The EU energy system needs undergoing dramatic restructuring in the long-term, including disruptive changes in the way of consuming and distributing energy to consumers, to achieve carbon-neutrality. Policy-making faces important strategic dilemmas regarding the choice of the dominant technology and energy form that will drive the disruptive changes. Irrespective of the choices for the disruptive changes, this model-based analysis suggests maintaining as basic pillars the strong enhancement of energy efficiency, the development of renewables at a large-scale, in particular in the power sector, the electrification of heat and mobility in the market segments where this is cost-effective and the development of advanced biofuels depending on their potential. Policy-making should consider the pillars as no-regrets options, but this is not enough to deliver full carbon-neutrality in the EU by 2050 and beyond. At present, the assessment of additional measures to achieve carbon neutrality is not yet conclusive. The main reason is the huge uncertainty surrounding the future costs and success of technologies which are not currently mature at an industrial level. 
The detailed modelling of the EU energy system up to 2050 with the inclusion of new technologies for GHG-free hydrogen and hydrocarbons supports the statement that carbon-neutrality by 2050 is feasible and reachable through a dynamic restructuring pathway. The 2030 targets are an essential milestone in all pathways. Development of infrastructure and industrial development of technologies not yet mature are key achievements that the pathways have to deliver starting already in the next decade. The modelling assumed perfect conditions regarding the coordination of agents, the anticipation by investors and integration within the EU. They are essential for the long transition to succeed. Failures will be detrimental for costs and the feasibility of reaching carbon neutrality.

In all stylized cases, industrial maturity of today immature technologies is key for achieving an affordable transition. Cost reduction via learning-by-doing depends on large-scale investment, which in turn strongly depends on the visibility of sufficiently large market development in the future. Public policy has a critical role to play to ensure long-term visibility of potential investors in the new technologies. However, when technologies compete with each other and uncertainty prevails about their future potential, public policy often opts for measure respecting technology neutrality to avoid risks of promoting the "wrong" technology. However, a lack of clear visibility of future markets weakens capital accumulation and delays the learning process. The synchronous pursuit of all technology pathways is a valid option only in the early stages of development. When technology uncertainty reduces, public policy has to make decisions and select a few of the technology routes for eventual financial promotion, investment in enabling infrastructure and adoption of suitable technology norms and standards.

Although few technology routes will survive in the markets in the long-term, the full dominance of a single option also has its drawbacks. For instance, lack of competition between technology options and energy carriers weakens cost-efficiency and consumers are vulnerable to the exercise of market power. Moreover, using a single technology option in all applications implies pressures on costs due wither to the exhaustion of potentials or the inappropriateness of the option in some applications.

The modelling, presented in this paper, explored the contrasting options supporting disruptive changes through stylized scenarios that opted for a single dominant technology or energy form, namely extreme electrification, a hydrogen economy and the development of hydrogen together with synthetic GHG-free methane and liquid hydrocarbons. All three options have to address considerable uncertainties in some market segments. Maximum electrification would be difficult in aviation, shipping and some industrial processes. A full hydrogen economy would have difficulty in implementing a complete hydrogen distribution and storage infrastructure. A synthetic hydrocarbons strategy may imply unsustainable volumes of the power sector. For these reasons, all three strategies need to keep in place the no-regrets options.

The balanced scenario illustrates an optimal combination of hydrogen uses and development of synthetic methane. The power sector benefits from chemical storage and maximizes renewables, thus addressing the increase in demand sustainably and affordably. The model results confirmed the importance of chemical storage for balancing renewables in the power sector and hence, it is imperative to develop hydrogen at least for chemical storage of electricity. Hydrogen is a cost-effective option in specific market segments, such as direct uses in energy-intensive industries, fueling heavy-duty transport means and contributing to decarbonization of distributed gas up to a $15 \%$ vol. GHG-free methane combined with biogas and hydrogen ensures a full greening of distributed gas, which has the merit of maintaining current infrastructure, equipment and convenience of use. Electrification is strong and confined to transport market segments (e.g., cities), as well as heat uses where it is cost-effective. Advanced biofuels address transport market segments where they are of high value, such as in aviation. The balanced scenario avoids risky choices from technological and investment perspectives and is, therefore, more feasible compared to the three other stylized strategies.

Regarding the policies and measures, the modelling of the scenarios combined market-based policy instruments, such as EU-ETS carbon prices, efficiency supporting policies (including measures removing non-market barriers) and technology standards, like carbon emission standards for cars, 
eco-design regulations, etc. The model has also included emission performance standards combined with guarantees of origin to enable GHG-free gas in the distribution system based on the blending of biofuels, hydrogen and GHG-free methane. Carbon pricing included in the power system model drove GHG-free production of hydrogen and synthetic fuels. Investment in infrastructure in all sectors was exogenous in the modelling of the scenarios, assuming to be driven by public policy.

The assessment of cost impacts, based on the model, has shown that the increase in costs for the consumers is small compared to the amplitude of transformations and restructuring. Economies of scale and the achievement of the learning potential are important prerequisites. The cost structure evolves towards a string increase in capital expenditures (CAPEX) and a slight decrease in operating expenses $(\mathrm{OPEX}$,$) in the entire energy system. Dependence on investment funding is consequently an important$ factor to be taken into consideration. Investment in the demand sectors needs special attention. Firstly because of the large volume of capital required for the transition. Secondly, because a large part concerns the investment possibilities of individuals, who, depending on income conditions, may lack capital funding or may face non-market barriers obstructing investment decisions-policies combatting energy poverty will have to also address the eventual lack of sufficient technology investment by low-income classes.

Author Contributions: S.E. is the main researcher for the modelling presented in the paper. A.D.V. has contributed to the research for policy analysis and consultation with the industry. G.Z. acted as coordinator of the PRIMES modelling and contributed to the enhancement of the model. P.C. is the scientific coordinator and supervisor of the research.

Funding: The European Commission partially funded this research within a Long-Range Energy Modelling Framework contract.

Acknowledgments: The authors acknowledge modelling contributions by M. Kannavou (power sector), P. Siskos (transport sector) and Th. Fotiou (buildings sector).

Conflicts of Interest: The authors declare no conflict of interest. The opinions expressed in this article are those of the authors and do not necessarily reflect the views of the European Commission.

\section{References}

1. Barker, T.; Bergall, O.; Bodin, S.; Cassel-Gintz, M.; Cornelius, S.; De Brabante, E.; Fuentes, U.; Füssel, H.-M.; Gillet, M.; Hain, B.; et al. The $2{ }^{\circ} \mathrm{C}$ target. Information Reference Document; EU Climate Change Expert Group, 2008. Available online: https://www.climateemergencyinstitute.com/uploads/2C_EU.pdf (accessed on 29 April 2019).

2. IPCC. Climate Change 2014: Synthesis Report. Contribution of Working Groups I, II and III to the Fifth Assessment Report of the Intergovernmental Panel on Climate Change; Pachauri, R.K., Meyer, L.A., Eds.; IPCC: Geneva, Switzerland, 2014; p. 151.

3. European Commission. Clean Planet for all a European Long-Term Strategic Vision for a Prosperous, Modern, Competitive and Climate Neutral Economy, in-Depth Analysis in Support of the Commission Communication. COM/2018/773 A; European Commission: Brussels, Belgium, 2018.

4. Capros, P.; Paroussos, L.; Fragkos, P.; Tsani, S.; Boitier, B.; Wagner, F.; Busch, S.; Resch, G.; Blesl, M.; Bollen, J. Description of models and scenarios used to assess European decarbonization pathways. Energy Strateg. Rev. 2014, 2, 220-230. [CrossRef]

5. Capros, P.; Paroussos, L.; Fragkos, P.; Tsani, S.; Boitier, B.; Wagner, F.; Busch, S.; Resch, G.; Blesl, M.; Bollen, J. European decarbonization pathways under alternative technological and policy choices: A multi-model analysis. Energy Strateg. Rev. 2014, 2, 231-245. [CrossRef]

6. Capros, P.; Kannavou, M.; Evangelopoulou, S.; Petropoulos, A.; Siskos, P.; Tasios, N.; Zazias, G.; DeVita, A. Outlook of the EU energy system up to 2050: The case of scenarios prepared for European Commission's Clean energy for all Europeans package using the PRIMES model. Energy Strateg. Rev. 2018, 22, 255-263. [CrossRef]

7. EURELECTRIC. Energy Roadmap 2050. February 2012. Available online: https://www.eurelectric.org/media/ 1698/roadmap_2050_response_paper_final-2012-100-0003-01-e.pdf (accessed on 29 April 2019). 
8. FCH Europa. Hydrogen Roadmap Europe-A Sustainable Pathway for the European Energy Transition. 2019. Available online: https://fch.europa.eu/sites/default/files/Hydrogen\%20Roadmap\%20Europe_Report.pdf (accessed on 29 April 2019).

9. Blanco, H.; Nijs, W.; Ruf, J.; Faaij, A. Potential for hydrogen and power-to-liquid in a low-carbon EU energy system using cost optimization. Appl. Energy 2018, 232, 617-639. [CrossRef]

10. Staffell, I.; Scamman, D.; Abad, A.V.; Balcombe, P.; Dodds, P.E.; Ekins, P.; Shah, N.; Ward, K.R. The role of hydrogen and fuel cells in the global energy system. Energy Environ. Sci. 2019, 12, 463-491. [CrossRef]

11. Hanley, E.S.; Deane, J.P.; Gallachóir, B.Ó. The role of hydrogen in low carbon energy futures-A review of existing perspectives. Renew. Sustain. Energy Rev. 2018, 82, 3027-3045. [CrossRef]

12. Kanellopoulos, K.; Blanco Reano, H. The Potential Role of $\mathrm{H}_{2}$ Production in a Sustainable Future Power System-An Analysis with METIS of a Decarbonized System Powered by Renewables in 2050, EUR 29695 EN; JRC115958; Publications Office of the European Union: Luxembourg, 2019; ISBN 978-92-76-00820-0. [CrossRef]

13. Blanco, H.; Nijs, W.; Ruf, J.; Faaij, A. Potential of power-to-methane in the EU energy transition to a low carbon system using cost optimization. Appl. Energy 2018, 232, 323-340. [CrossRef]

14. Dodds, P.E.; Demoullin, S. Conversion of the UK gas system to transport hydrogen. Int. J. Hydr. Energy 2013, 38, 7189-7200. [CrossRef]

15. Strbac, G.; Pudjianto, D.; Sansom, R.; Djapic, P.; Ameli, H.; Shah, N.; Brandon, N.; Hawkes, A.; Qadrdan, M. Analysis of Alternative UK Heat Decerbonisation Pathways; Imperial College London: London, UK, 2018; Available online: https://www.theccc.org.uk/publication/analysis-of-alternative-uk-heat-decarbonisationpathways/ (accessed on 29 April 2019).

16. De Joode, J.; Daniëls, B.W.; Smekens, K.; Van Stralen, J.; Dalla Longa, F.; Schoots, K.; Seebregts, A.; Grond, L.; Holstein, J. Exploring the Role for Power-to-Gas in the Future Dutch Energy System. Final Report of The TKI Power-to-Gas System Analysis Project; ECN: Petten, The Netherlands, 2014.

17. Thomas, D.; Mertens, D.; Meeus, M.; Van der Laak, W.; Francois, I. Power-to-Gas. Roadmap for Flanders, October 2016. Available online: https://www.power-to-gas.be/ (accessed on 29 April 2019).

18. McKenna, R.C.; Bchini, Q.; Weinand, J.M.; Michaelis, J.; König, S.; Köppel, W.; Fichtner, W. The future role of Power-to-Gas in the energy transition: Regional and local techno-economic analyses in Baden-Württemberg. Appl. Energy 2018, 212, 386-400. [CrossRef]

19. International Energy Agency. The Future of Hydrogen. Seizing Today's Opportunities; Report Prepared by the IEA for the G20, Japan; IEA: Paris, France, 2019; Available online: https://www.iea.org/hydrogen2019/ (accessed on 24 June 2019).

20. E3Mlab. PRIMES Model Primes Model 2018, Detailed Model Description; National Technical University of Athens: Athens, Greece, 2018; Available online: http://www.e3mlab.eu/e3mlab/PRIMES\%20Manual/The\% 20PRIMES\%20MODEL\%202018.pdf (accessed on 29 April 2019).

21. Ramachandran, R.; Menon, R.K. An overview of industrial uses of hydrogen. Int. J. Hydr. Energy 1998, 23, 593-598. [CrossRef]

22. Fraile, D.; Lanoix, J.C.; Maio, P.; Rangel, A.; Torres, A. Overview of the Market Segmentation for Hydrogen Across Potential Customer Groups, Based on Key Application Areas. CertifHy, June 2015. Deliverable No. 1.2. Available online: http://www.certifhy.eu/images/D1.1_Bibliographic_review_of_market_outlooks_for_ hydrogen_in_Europe.pdf (accessed on 29 April 2019).

23. Dolci, F. Green Hydrogen Opportunities in Selected Industrial Processes-Workshop Summary Report (26th of June 2018, Centre Albert Borschette, Brussels, Belgium), EUR 29637 EN; JRC114766; Publications Office of the European Union: Luxembourg, 2018; ISBN 978-92-79-99135-6. [CrossRef]

24. Shell. Shell Hydrogen Study: Sustainable Mobility through FUel Cells and $\mathrm{H}_{2}$; Shell: Hamburg, Germany, 2017; Available online: https://www.shell.com/energy-and-innovation/new-energies/hydrogen.html (accessed on 29 April 2019).

25. Berger, R. Fuel Cell Electric Buses_Potential for Sustainable Public Transport in Europe: A Study for the FUel Cells and Hydrogen Joint Undertaking; FCH JU: München, Germany, 2015; Available online: https://www.fch.europa. eu/sites/default/files/150909_FINAL_Bus_Study_Report_OUT_0.PDF (accessed on 29 April 2019).

26. Hart, D.; Howes, J.; Lehner, F.; Dodds, P.; Hughes, N.; Fais, B.; Sabio, N.; Crowther, M. Scenarios for Deployment of Hydrogen in Contributing to Meeting Carbon Budgets and the 2050 Target. E4tech, UCL Energy Institute, University College London, Kiwa Gastec, October 2015. Available online: http://www.e4tech.com/reports/ scenarios-for-deployment-of-hydrogen-in-meeting-carbon-budgets/ (accessed on 29 April 2019). 
27. Alstom. Coradia iLint- the Word's 1st Hydrogen Power Train. Available online: https://www.alstom.com/ our-solutions/rolling-stock/coradia-ilint-worlds-1st-hydrogen-powered-train (accessed on 29 April 2019).

28. Ballard. Zero-Emission Drayage Trucks: Technology and Proven Capabilities; Ballard: London, UK, May 2018; Available online: https://blog.ballard.com/fuel-cell-drayage-trucks (accessed on 29 April 2019).

29. Pocard, N.; Reid, C. Fuel Cell Electric Buses: An Attractive Value Proposition for Zero-Emission Buses in the United Kingdom; Balard: London, UK, 2016; Available online: https://www.fuelcellbuses.eu/sites/default/files/ Ballard\%20-\%20fuel\%20cell\%20electric\%20buses.pdf (accessed on 29 April 2019).

30. International Energy Agency. Technology Roadmap: Hydrogen and Fuel Cells; IEA: Paris, France, 2015; Available online: https:/www.iea.org/publications/freepublications/publication/ TechnologyRoadmapHydrogenandFuelCells.pdf (accessed on 29 April 2019).

31. Melaina, M.; Penev, M. Hydrogen Station Cost Estimates. Comparing Hydrogen Station Cost Calculator Results with other Recent Estimates. National Renewable Energy Laboratory; NREL. NREL/TP-5400-56412; September 2013. Available online: https://www.nrel.gov/docs/fy13osti/56412.pdf (accessed on 29 April 2019).

32. Hart, D.; Howes, J.; Madden, B.; Boyd, E. Hydrogen and Fuel Cells: Opportunities for Growth. A Roadmap for the UK. E4Tech; Element Energy: November 2016. Available online: http://www.e4tech.com/reports/ hydrogen-and-fuel-cells-opportunities-for-growth-a-roadmap-for-the-uk/ (accessed on 29 April 2019).

33. Dodds, P.E.; Staffell, I.; Hawkes, A.D.; Li, F.; Grünewald, P.; McDowall, W.; Ekins, P. Hydrogen and fuel cell technologies for heating: A review. Int. J. Hydr. Energy 2015, 40, 2065-2083. [CrossRef]

34. Hofmeister, M.; Guddat, M. Techno-Economic Projections Until 2050 for Smaller Heating and Cooling Technologies in the Residential and Tertiary Sector in the EU. EUR28861; JRC109034; Publications Office of the European Union: Luxembourg, 2017; ISBN 978-92-79-76014-3. [CrossRef]

35. Dodds, P.E.; Hawkes, A.; McDowall, W.; Li, F.; Staffell, I.; Grünewald, P.; Kansara, T.; Ekins, P.; Agnolucci, P. The Role of Hydrogen and Fuel Cells in Providing Affordable, Secure Low-Carbon Heat; H2FC SUPERGEN: London, UK, 2014; Available online: http://www.h2fcsupergen.com/wp-content/uploads/2014/05/H2FC-SUPERGENWhite-Paper-on-Heat-May-2014.pdf (accessed on 29 April 2019).

36. Melaina, M.W.; Antonia, O.; Penev, M. Blending Hydrogen into Natural Gas. Pipeline Networks: A Review of Key Issues; Technical Report NREL/TP-5600-51995; National Renewable Energy Laboratory (NREL): Lakewood, CO, USA, 2013. Available online: https://www.nrel.gov/docs/fy13osti/51995.pdf (accessed on 29 April 2019).

37. Decourt, B.; Lajoie, B.; Debarre, R.; Soupa, O. Hydrogen-Based Energy Conversion. More than Storage: System Flexibitily; SBC Energy Institute: Melbourne, Australia, 2014.

38. Chiesa, P.; Lozza, G.; Mazzocchi, L. Using hydrogen as gas turbine fuel. Trans. ASME A Eng. Gas. Turbines Power 2005, 127, 73-80. [CrossRef]

39. Götz, M.; Lefebvre, J.; Mörs, F.; Koch, A.M.; Graf, F.; Bajohr, S.; Kolb, T. Renewable power-to-gas: A technological and economic review. Renew. Energy 2016, 85, 1371-1390. [CrossRef]

40. Maroufmashat, A.; Fowler, M. Transition of future energy system infrastructure; through power-to-gas pathways. Energies 2017, 10, 1089. [CrossRef]

41. Connolly, D.; Mathiesen, B.V.; Ridjan, I. A comparison between renewable transport fuels that can supplement or replace biofuels in a 100\% renewable energy system. Energy 2014, 73, 110-125. [CrossRef]

42. Varone, A.; Ferrari, M. Power to liquid and power to gas: An option for the German Energiewende. Renew. Sustain. Energy Rev. 2015, 45, 207-218. [CrossRef]

43. Schmidt, P.; Weindorf, W.; Roth, A.; Batteiger, V.; Riegel, F. Power-to-Liquids_Potentials and Perspectives for the Future Supply of Renewable Aviation Fuel; Umwelt Bundesamt; German Environment Agency: Munich, Germany, 2016; Available online: https://www.umweltbundesamt.de/en/publikationen/power-to-liquidspotentials-perspectives-for-the (accessed on 29 April 2019).

44. Blanco, H.; Faaij, A. A review at the role of storage in energy systems with a focus on power to gas and long-term storage. Renew. Sustain. Energy Rev. 2018, 81, 1049-1086. [CrossRef]

45. Wulf, C.; Linßen, J.; Zapp, P. Review of power-to-gas projects in Europe. Energy Procedia 2018, 155, 367-378. [CrossRef]

46. Fendt, S.; Buttler, A.; Gaderer, M.; Spliethoff, H. Comparison of synthetic natural gas production pathways for the storage of renewable energy. Wiley Interdiscip. Rev. Energy Environ. 2016, 5, 327-350. [CrossRef]

47. Bucy, J.; Lacroix, O.; Jammes, L. The Potential of Power-to-Gas; ENEA Consulting: Paris, France, 2016; Available online: https://www.enea-consulting.com/en/the-potential-of-power-to-gas/ (accessed on 29 April 2019). 
48. Götz, M.; Koch, A.M.; Graf, F. State of the art and perspectives of $\mathrm{CO}_{2}$ methanation process concepts for power-to-gas applications. In International Gas Union Research Conference; International Gas Union: Fornebu, Norway, 2014; Volume 13.

49. Schiebahn, S.; Grube, T.; Robinius, M.; Tietze, V.; Kumar, B.; Stolten, D. Power to gas: Technological overview, systems analysis and economic assessment for a case study in Germany. Int. J. Hydr. Energy 2015, 40, 4285-4294. [CrossRef]

50. Perner, J.; Unteutsch, M.; Lövenich, A. The Future Cost of Electricity Based Synthetic Fuels. Frontier Economics for Agora Verkehrswende and Agora Energiewende and Frontier Economics. September 2018. 133/06-S-2018/EN. Available online: https://www.agoraenergiewende.de/fileadmin2/Projekte/2017/SynKost_ 2050/Agora_SynKost_Study_EN_WEB.pdf (accessed on 29 April 2019).

51. Navigant Consulting. Gas for Climate. The optimal Role for Gas in a Net Zero Emissions Energy System; Navigant: Utrecht, The Netherlands, 2019; No.: 203997; Available online: https://www.gasforclimate2050.eu/ publications (accessed on 29 April 2019).

52. Parkinson, B.; Balcombe, P.; Speirs, J.F.; Hawkes, A.D.; Hellgardt, K. Levelized cost of $\mathrm{CO}_{2}$ mitigation from hydrogen production routes. Energy Environ. Sci. 2019, 12, 19-40. [CrossRef]

53. Littlecott, C.; Pearson, I.; Whiriskey, K.; Skriung, C.S. Moving CCS Forward in Europe. ENGO Network on CCS; E3G, Bellona Foundation, Zero Emissions Resource Organisation: Melbourne, Australia, 2013; Available online: https://www.e3g.org/docs/ENGO_Network_on_CCS_-_Moving_CCS_forward_in_Europe_final.pdf (accessed on 29 April 2019).

54. Huijts, N.M.; Midden, C.J.; Meijnders, A.L. Social acceptance of carbon dioxide storage. Energy Policy 2007, 35, 2780-2789. [CrossRef]

55. Selma, L.; Seigo, O.; Dohle, S.; Siegrist, M. Public perception of carbon capture and storage (CCS): A review. Renew. Sustain. Energy Rev. 2014, 38, 848-863. [CrossRef]

56. Van Cappellen, L.; Croezen, H.; Rooijers, F. Feasibility Study into Blue Hydrogen. Technical, Economic $\mathcal{E}$ Sustainability Analysis; Publication code: 18.9901.095; CE Delft: Delft, The Netherlands, 2018; Available online: www.cedelft.eu (accessed on 29 April 2019).

57. De Vita, A.; Kielichowska, I.; Mandatowa, P.; Capros, P.; Dimopoulou, E.; Evangelopoulou, S.; Fotiou, T.; Kannavou, M.; Siskos, P.; Zazias, G.; et al. Technology Pathways in Decarbonization Scenarios; Tractebel, Ecofys, E3-Modelling: Brussels, Belgium, 2018; Available online: https:/ec.europa.eu/energy/sites/ener/files/ documents/2018_06_27_technology_pathways_-_finalreportmain2.pdf (accessed on 29 April 2019).

58. Jordbakke, G.N.; Amundsen, A.; Sundvor, I.; Figenbaum, E.; Hovi, I.B. Technological Maturity Level and Market Introduction Timeline of Zero-Emission Heavy Duty Vehicles. 1655/2018; Institute of Transport Economics: Oslo, Norway, 2018; Available online: https://www.toi.no/getfile.php?mmfileid=48918 (accessed on 29 April 2019).

59. Brelje, B.J.; Martins, J.R. Electric, hybrid, and turboelectric fixed-wing aircraft: A review of concepts, models, and design approaches. Prog. Aerosp. Sci. 2019, 104, 1-19. [CrossRef]

60. IEA HPP-IETS Annex 35/13. Application of Industrial Heat Pumps; International Energy Agency (IEA), Energy-Related Technologies and Systems (IETS), Heat Pump Programme (HPP), 2014. Available online: https://iea-industry.org/app/uploads/annex-xiii-part-a.pdf (accessed on 29 April 2019).

61. Beyond Zero Emissions. Zero Carbon Industry Plan: Electrifying Industry; Beyond Zero Emissions Inc.: Melbourne, Australia, 2018; Available online: http://bze.org.au (accessed on 29 April 2019).

62. Bockris, J.O.M. The hydrogen economy: Its history. Int. J. Hydr. Energy 2013, 38, 2579-2588. [CrossRef]

63. Quarton, C.J.; Samsatli, S. Power-to-gas for injection into the gas grid: What can we learn from real-life projects, economic assessments and systems modelling? Renew. Sustain. Energy Rev. 2018, 98, 302-316. [CrossRef]

64. Schobert, H.H. Production and Use of Synthesis Gas. Available online: https://www.elsevier.com/books/thechemistry-of-hydrocarbon-fuels/schobert/978-0-408-03825-6 (accessed on 2 July 2019).

65. Rosa, R. The role of synthetic fuels for a carbon neutral economy. C 2017, 3, 11. [CrossRef]

66. Smith, P.; Davis, S.J.; Creutzig, F.; Fuss, S.; Minx, J.; Gabrielle, B.; Kato, E.; Jackson, R.B.; Cowie, A.; Kriegler, E.; et al. Biophysical and economic limits to negative $\mathrm{CO}_{2}$ emissions. Nat. Clim. Chang. 2016, 6, 42. [CrossRef]

67. Simon, A.J.; Kaahaaina, N.B.; Friedmann, S.J.; Aines, R.D. Systems analysis and cost estimates for large scale capture of carbon dioxide from air. Energy Procedia 2011, 4, 2893-2900. [CrossRef]

68. Holmes, G.; Keith, D.W. An air-liquid contactor for large-scale capture of $\mathrm{CO}_{2}$ from air. Philos. Trans. R. Soc. A Math. Phys. Eng. Sci. 2012, 370, 4380-4403. [CrossRef] 
69. Ishimoto, Y.; Sugiyama, M.; Kato, E.; Moriyama, R.; Tsuzuki, K.; Kurosawa, A. Putting costs of direct air capture in context. In Forum for Climate Engineering Assessment; School of International Service, American University: Washington DC, USA, 2017.

70. E3MLAB; IIASA. Technical Report on Member State Results of the EUCO Policy Scenarios. December 2016. Available online: https://ec.europa.eu/energy/sites/ener/files/documents/20170125_-_technical_report_on_ euco_scenarios_primes_corrected.pdf (accessed on 29 April 2019).

71. European Commission. Clean Energy for All Europeans, Communication from the Commission to the European Parliament, the Council, the European Economic and Social Committee and the Committee of the Regions and the European Investment Bank; European Commission: Brussels, Belgium, 2016; Available online: https://ec.europa. eu/energy/en/news/commission-proposes-new-rules-consumer-centred-clean-energy-transition (accessed on 29 April 2019).

(C) 2019 by the authors. Licensee MDPI, Basel, Switzerland. This article is an open access article distributed under the terms and conditions of the Creative Commons Attribution (CC BY) license (http://creativecommons.org/licenses/by/4.0/). 